\title{
Sporadic calcitonin-negative medullary thyroid carcinoma is not more aggressive than its classic counterpart: case report and review of the literature
}

\author{
John J. Orrego, M.D. ${ }^{1}$, Joseph A. Chorny, M.D. ${ }^{2}$
}

${ }^{1}$ Department of Endocrinology and Metabolism, Colorado Permanente Medical Group 1375 East $20^{\text {th }}$ Avenue, Denver CO 80205. Email: John.J.Orrego@kp.org

${ }^{2}$ Department of Pathology, Colorado Permanente Medical Group 11000 East $45^{\text {th }}$ Street, Denver, CO 80239. Email:

Loseph.A.Chorny@kp.org

Dr John J. Orrego does not have any conflict of interest. Dr Joseph A. Chorny does not have any conflict of interest.

Fecha de recepción: 8/09/2016

Fecha de aceptación: 26/10/2016

\section{Abstract}

Objective: medullary thyroid carcinoma (MTC) with normal serum basal calcitonin (calcitonin-negative MTC) is uncommon. The exact mechanism for this paradox is unclear. It has been suggested that the loss of ability to secrete calcitonin is due to tumor cell dedifferentiation and may confer a worse prognosis.

Methods: we describe a 45-year-old woman with a sporadic 4.5-cm well-differentiated MTC, who despite having normal preoperative serum basal calcitonin and poor calcitonin immunostaining in tumor cells, remains in remission 5 years after total thyroidectomy with bilateral central neck dissection. Out of the 20 patients with calcitonin-negative MTC reported to date, we include 16 patients with clinical disease at presentation to determine if they fare worse than their classic MTC counterparts. We try to correlate the extent of calcitonin immunostaining with the degree of tumor differentiation to determine if poor tumor calcitonin immunoreactivity is an indicator of tumor cell dedifferentiation.

Results: Seven and 9 patients with calcitonin-negative MTC had poorly-differentiated and well-differentiated tumors, respectively. Four patients in the former group died from metastatic MTC within 3 years of the diagnosis. The status of the 2 living patients with known follow-up information was one with N1 disease and one in remission. In the well-differentiated group, 2 patients had N1M1 disease and 7 patients were in remission.
According to the number of tumor cells immunoreactive to calcitonin, the 15 patients with known data were classified in 3 groups: 1+ group (only few tumor cells stained weakly for calcitonin), 7 patients; $2+$ group (many tumor cells stained focally for calcitonin), 2 patients; and $3+$ group (most tumor cells stained strongly for calcitonin), 6 patients. The level of calcitonin immunoreactivity did not correlate with the patient's clinical status.

Conclusion: the degree of tumor differentiation is a far better predictor of outcome than the extent of calcitonin immunoreactivity and poor tumor calcitonin staining is not necessarily an indicator of tumor cell dedifferentiation.

Keywords: Medullary thyroid carcinoma= carcinoma medular de tiroides. Calcitonine-negative= calcitonina negativa . Nonsecretory tumor= tumor no secretor. Calcitonin immunostaining= inmunotinción para calcitonina. Poorly differentiated cancer $=$ cancer pobremente diferenciado

\section{Introduction}

Medullary thyroid carcinoma (MTC) is a rare neuroendocrine thyroid malignancy that accounts for fewer than $5 \%$ of all thyroid cancers. MTC, which arises from the parafollicular C cells of the thyroid gland, is sporadic in $75-80 \%$ of affected patients.

MTC tumor cells synthesize and secrete a variety of peptides that can be used as tumor markers. Serum calcitonin is the most sensitive biomarker and has a primary role for screening, diagnosis, staging, postsurgical management, prognostic assessment, and follow-up monitoring ${ }^{(1,2)}$. The bioactive or mature form of calcitonin, a 32 amino acid monomeric peptide, is produced by cleavage and post-translational processing of procalcitonin ${ }^{(3)}$.

The great majority of patients with sporadic MTC have basal hypercalcitoninemia ${ }^{(4)}$. However, some patients with unequivocally proven MTC and normal or undetectable basal serum calcitonin levels have been described ${ }^{(5-16)}$. These patients also tend to have normal levels of CEA and chromogranin A. The terms "calcitonin-negative" or "nonsecretory" MTC have 
been coined for these tumors and the exact mechanism for this apparent paradox is currently unknown. It has been suggested that the loss of ability to secrete calcitonin is due to tumor cell dedifferentiation and may confer a worse prognosis ${ }^{(17)}$.

We describe a 45-year-old female with sporadic MTC, who despite having normal preoperative basal serum calcitonin levels and poor calcitonin immunostaining in tumor cells, is still in remission 5 years after total thyroidectomy and bilateral central neck dissection. We compiled previous case reports of calcitonin-negative (cn) MTC showing that the absence of calcitonin secretion by tumor cells does not equate dedifferentiation and therefore, more aggressive tumor behavior.

\section{Case presentation}

A 45-year-old female presented in June 2010 with a rightsided neck mass. She denied dysphonia, dyspnea, choking sensation, diarrhea, or flushing. She reported no personal history of radiation exposure or family history of thyroid cancer. On physical examination, a large, firm, mobile, nontender right thyroid nodule was palpated. TSH was normal. Thyroid ultrasound scanning demonstrated a right-sided, $4.9 \times 2.5 \times 3.1 \mathrm{~cm}$ (sagittal $\mathrm{x}$ anterior/posterior $\mathrm{x}$ transverse), heterogeneous thyroid mass with microcalcifications and increased vascularity. The remainder of the thyroid gland was normal.

Fine-needle aspiration biopsy with ultrasound guidance was performed and cytopathology revealed numerous spindle cells with abundant pale cytoplasm, focal interdigitating cytoplasmic processes, and oval nuclei. There was evidence of mild nuclear variation with generally smooth nuclear membranes, slightly coarse chromatin and inconspicuous nucleoli. Findings were consistent with MTC.

Fasting serum calcitonin $(3.0 \mathrm{pg} / \mathrm{mL}$; normal: < 5), CEA (1.3 ng/mL; normal: 0-4.6), and chromogranin A (2.4 ng/mL; normal: 1.9-15) were within the normal reference range; as well as plasma free metanephrines, PTH and calcium. The calcitonin test was performed using the Siemens (DPC) chemiluminescent method (Quest Diagnostics Nichols Institute, Chantilly, VA). Sequencing of the RET proto-oncogene revealed no germline mutations for MEN.

Preoperative contrast-enhanced CT scans of the neck and chest revealed a $4.5 \times 3.0 \times 3.7-\mathrm{cm}$ (sagittal x anterior/posterior $x$ transverse) right thyroid mass with no extra thyroidal extension and no cervical or mediastinal lymphadenopathy or lung metastases.

She underwent total thyroidectomy with bilateral central neck dissection in October 2010. Histopathology confirmed a 4.5-cm well-differentiated MTC, which was confined to the right thyroid lobe. The margins were free and there was no lymphovascular invasion (figure 1). Eleven lymph nodes were negative for malignancy. The tumor was staged pT3, N0 M0 in the AJCC Cancer Staging TNM Classification. Immunoper-
Figure 1. The tumor is composed of discohesive spindle and epithelioid cells in nests (200X)

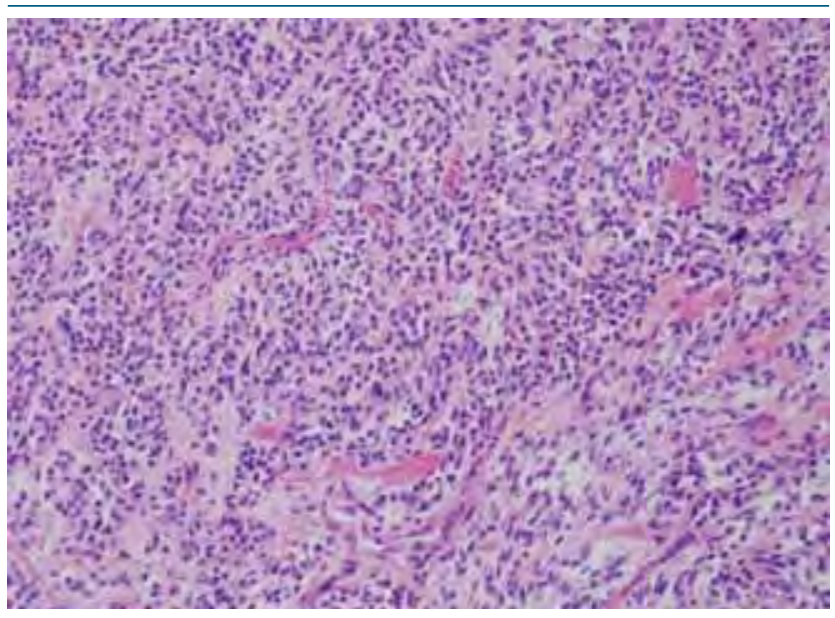

Figure 2. There are foci of weak positivity with a calcitonin immunostain (400X)

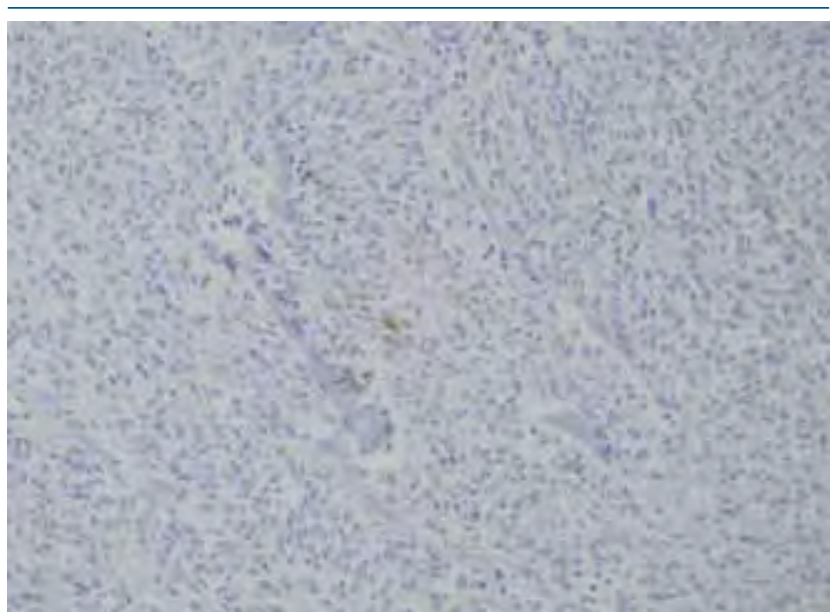

oxidase studies revealed that most tumor cells were strongly positive for CEA and chromogranin A, but only a few cells were focally and weakly positive for calcitonin (figure 2). The tumor cells also stained positively by immunohistochemistry for synaptophysin and CK7, but were negative for S100, TTF-1, and BCL2. The Ki67 proliferation index was $<1 \%$.

Two months after surgery, serum basal calcitonin was undetectable $(<2 \mathrm{pg} / \mathrm{mL})$ and has remained so for the past 5 years. CEA and chromogranin A levels remain normal. CT scans of her neck, chest and liver have revealed no metastatic disease.

\section{Discussion}

We describe a patient with sporadic MTC with normal preoperative basal serum calcitonin level. Despite typical cytology findings on fine-needle aspiration biopsy, which were confirmed on histopathological examination of the surgical specimen, only a few tumor cells were focally and weakly positive for calcitonin. 
To our knowledge, only 19 additional cases of "calcitoninnegative" MTC (cnMTC) have been reported to date ${ }^{(5-16)}$. A systematic review of the literature on this topic has been recently published $^{(18)}$. The prevalence of cnMTC is low. In a series of 839 patients with MTC, only seven of them had serum calcitonin levels that were below the upper limit of the normal range $(0.83 \%)^{(15)}$.

The exact mechanism(s) responsible for the inability of the tumor C cells of some patients with MTC to synthetize and/ or release calcitonin is unclear. Several hypotheses have been proposed $^{(5-16,18)}$, including post-translational modifications of calcitonin, secretion of calcitonin precursor peptides rather than mature calcitonin, the low specificity of polyclonal and monoclonal anti-calcitonin antibodies used for immunhistochemical staining for mature calcitonin, defective cellular mechanisms involved in the production and secretion of calcitonin, and dedifferentiation of tumor cells.

The idea that malignant $\mathrm{C}$ cells may produce calcitonin precursors rather than mature calcitonin is interesting. If this is true, preprocalcitonin and procalcitonin would not undergo cleavage and post-translational processing, with the subsequent accumulation of one or more of the peptides created during this process, including procalcitonin, aminoprocalcitonin and CCP-I. With the exception of Brutsaert et al.(16), who measured serum basal procalcitonin preoperatively, and found it to be elevated, no other authors, including us, measured any calcitonin precursors. In that case report, the patient's procal- citonin level became undetectable after successful thyroidectomy. This biomarker could be used for follow-up monitoring of patients presenting with normal serum calcitonin but elevated serum procalcitonin ${ }^{(16)}$.

Along these lines, the positive calcitonin inmunohistochemical staining of tumor cells in cnMTC could indicate that the polyclonal or monoclonal anti-calcitonin antibodies used are detecting calcitonin precursors rather than mature calcitonin. Indeed, the SP-17 rabbit monoclonal primary antibody (Ventana) used in our case for the immunohistochemical stain detection of calcitonin does detect other peptide proteins encoded by the calcitonin-related polypeptide alpha (CALCA) gene including calcitonin, calcitonin-gene related peptide and katacalcin, but not procalcitonin.

It has been suggested that the inability of the tumor cells to produce and secrete calcitonin is due to their dedifferentiation, which could be a marker of rapid tumor growth and worse prognosis. Saad et $\mathrm{al}^{(19)}$ found that patients with classic MTC and poor immunostaining for calcitonin, had more metastases and reduced 5-year survival rate. However, FrankRaue et $\mathrm{al}^{(15)}$ reported that the clinical course of cnMTC and poor immunoreactivity for calcitonin was not as dismal.

Twenty patients with cnMTC, including this case, have been published. The 16 patients with cnMTC who presented with clinical disease and harbored tumors $\geq 10 \mathrm{~mm}$ were analyzed to further clarify if calcitonin negativity is a bad prognostic indicator (table 1). The 4 patients with tumors $<10 \mathrm{~mm}$,

Table 1. Presentation of the 16 cases of cnMTC $\geq 10 \mathrm{~mm}$ in the literature. Staining for calcitonin: $1+$ is few cells with weak staining, $2+$ is many cells with focal staining, and $3+$ is diffuse and strong staining

\begin{tabular}{|c|c|c|c|c|c|}
\hline $\begin{array}{l}\text { Patient \# / } \\
\text { Author }\end{array}$ & $\begin{array}{c}\text { Tumor size, } \\
\text { mm }\end{array}$ & $\begin{array}{c}\text { Histopathology } \\
\text { MTC }\end{array}$ & $\begin{array}{l}\text { Calcitonin } \\
\text { staining }\end{array}$ & TMN Stage & Follow-up \\
\hline 1 Iglesias & unknown & PD & unknown & pTx Nx M1 & Died, 0.75 years \\
\hline 2 Bockhorn & 20 & PD & $1+$ & pT1 No M0 & In remission, 5 years \\
\hline 3 Sand & $>40$ & PD & $1+$ & pT3 N1 M1 & Died, 6 weeks \\
\hline 4 Dora & 17 & PD & $3+$ & pT1 N1 M0 & Unknown \\
\hline 5 Frank-Raue & 30 & PD & $2+$ & pT2 N1 M0 & Neck mets, 1.5 years \\
\hline 6 Frank-Raue & 18 & PD & $1+$ & pT1 N1 M1 & Died, 1.75 years \\
\hline 7 Frank-Raue & 55 & PD & $2+$ & pT3 N1 M1 & Died, 3 years \\
\hline 8 Redding & 45 & WD & $3+$ & pT3 NO MO & In remission, unknown duration \\
\hline 9 Giovanella & 45 & WD & $3+$ & pT3 NO MO & In remission, 2 years \\
\hline 10 Alapat & 30 & WD & $3+$ & pT2 NO MO & In remission, 20 months \\
\hline 11 Frank-Raue & 10 & WD & $1+$ & pT1 NO MO & In remission, 6 years \\
\hline 12 Frank-Raue & 80 & WD & $1+$ & pT4 N0 M1 & Neck and lung mets, 2.25 years \\
\hline 13 Frank-Raue & 20 & WD & $1+$ & pT1 N0 M0 & In remission, 12.5 years \\
\hline 14 Frank-Raue & 45 & WD & $3+$ & pT3 N1 M0 & Neck, bone, brain mets, 1.75 years \\
\hline 15 Brutsaert & 26 & WD & $3+$ & pT2 NO MO & In remission, unknown duration \\
\hline 16 Orrego & 45 & WD & $1+$ & pT3 NO MO & In remission, 5 years \\
\hline
\end{tabular}


which were found incidentally after surgery for nodular thyroid disease, were excluded. Seven patients with cnMTC had poorly-differentiated MTC (pdMTC) and of these, 4 died from metastatic MTC within 3 years of diagnosis. The remaining 9 patients had well-differentiated MTC (wdMTC) and all of them were alive. The status of the 2 living patients in the pdMTC group with known follow-up information was one with N1 disease and one in remission. In the wdMTC group, 2 patients had N1M1 disease and 7 patients were in remission. These data shows that patients with cnpdMTC have worse prognosis than those with cnwdMTC. Something similar has been shown in patients with classic MTC. Kakudo et al ${ }^{(20)}$ described 5 patients out of 64 with sporadic pdMTC and smaller secretory granules. All patients died from metastatic disease within 3 years of the initial diagnosis.

There was information about calcitonin immunostaining in 15 out of the 16 patients (table 1). In 7 of them, only few tumor cells stained weakly for calcitonin (1+ group); in 2 patients, many tumor cells stained focally for calcitonin (2+ group); and in 6 patients, most tumor cells stained strongly for calcitonin (3+ group). In the $1+$ group, 2 patients died, 1 had N1M1 disease, and 4 were in remission. In the $2+$ group, 1 patient died and 1 had N1M1 disease. In the 3+ group, 1 patient had N1M1 disease, 4 were in remission, and 1 had no follow-up information. These limited data suggest that the extent of calcitonin immunoreactivity is not a good prognostic predictor and that patients with cnMTC do not necessarily fare worse than their classic MTC counterparts. On the other hand, if the tumors are grouped by the degree of cell differentiation instead, it becomes evident that patients with cnpdMTC are more likely to die within 3 years of presentation than those with cnwdMTC.

Additionally, patients with sporadic MTC, whether classic or calcitonin-negative, appear to have similar TNM staging at presentation. Historically, around $50 \%$ of classic MTC patients are stage III and IV on initial presentation, compared with half of the $16 \mathrm{cnMTC}$ patients with tumors greater than 1 $\mathrm{cm}$ reported in this paper. Although 5 out of these 16 patients with cnMTC had distant metastases at diagnosis, compared with $10 \%$ of classic MTC patients frequently quoted in the literature, all but one patient had pdMTC, which we have shown here to carries a more dismal prognosis.

In summary, we report a patient with sporadic MTC, who despite having normal serum basal calcitonin levels and poor calcitonin immunostaining in tumor cells, is still in remission 5 years after total thyroidectomy and bilateral central neck dissection. The review of 15 additional cases of cnMTC showed that patients with this variant of MTC do not seem to fare worse than their classic MTC counterparts, and that normal basal serum calcitonin levels and poor calcitonin immunoreactivity are not markers of tumor cell dedifferentiation.

\section{References}

1. Hu MI, Ying AK, Jimenez C. Update on medullary thyroid cancer. Endocrinol Metab Clinics North Am. 2014;43:423-442.

2. De Groot JW, Kema IP, Breukelman H. Biochemical markers in the follow-up of medullary thyroid cancer. Thyroid. 2006;16:1163-1170.

3. Inzerillo AM, Zaidi M, Huang CL. Calcitonin: the other thyroid hormone. Thyroid. 2002;12:791-798.

4. Kebebew E, Ituarte PH, Siperstein AE, Duh QY, Clark OH. Medullary thyroid carcinoma: clinical characteristics, treatment, prognostic factors, and a comparison of staging systems. Cancer. 2000;88:1139-1148.

5. Iglesias P, Vicandi B, Ortega P, Diez JJ. Variante anaplasica del carcinoma medular de tiroides. Med Clin (Barc). 1997;109:276.

6. Diez JJ, Iglesias P. Lack of elevated serum carcinoembryonic antigen and calcitonin in medullary thyroid carcinoma. Thyroid. 2004;14:984-985.

7. Niccoli P, Wion-Barbot N, Caron P, Henry JF, de Micco C, Saint Andre JP. Interest of routine measurement of serum calcitonin: study in a large series of thyroidectomized patients. The French Medullary Study Group. J Clin Endocrinol Metab. 1997;82:338-341.

8. Redding AH, Levine SN, Fowler MR. Normal preoperative calcitonin levels not always exclude medullary thyroid carcinoma in patients with large palpable thyroid masses. Thyroid. 2000;10:919-922.

9. Bockhorn M, Frilling A, Rewerk S, Liedke M, Dirsch O, Schmid KW. Lack of elevated serum carcinoembryonic antigen and calcitonin in medullary thyroid carcinoma. Thyroid. 2004;14:468-470.

10. Sand M, Gelos M, Sand D, Bechara FG, Bonhag G, Welsing E, Mann B. Serum calcitonin negative medullary thyroid carcinoma. World J Surg Oncol. 2006;4:97-100.

11. Dora JM, Canalli MH, Capp C, Puñales MK, Vieira JG, Maia AL. Normal perioperative serum calcitonin levels in patients with advanced medullary thyroid carcinoma: case report and review of the literature. Thyroid. 2008;18:895899.

12. Giovanella L, Crippa S, Cariani L. Serum calcitonin-negative medullary thyroid carcinoma: role of CgA and CEA as complementary markers. Int J Biol Markers. 2008;23:129-131.

13. Chambon G, Alovisetti C, Idoux-Louche C, Reynaud C, Rodier M, Guedj AM. J Clin Endocrinol Metab. 2011;96:75-81.

14. Alapat DV, Ain KB, Sloan DA, Monaghan KG, Karabakhtsian RG. Disparity between tissue and serum calcitonin and carcinoembryonic antigen in a patient with medullary thyroid carcinoma. Endocrine. 2011;39:148-152.

15. Frank-Raue K, Machens A, Leidig-Bruckner G, Rondot S, Haag C, Schulze E Prevalence and clinical spectrum of nonsecretory medullary thyroid carcinoma in a series of 839 patients with sporadic medullary thyroid carcinoma. Thyroid. 2013;23:294-300.

16. Brutsaert EF, Gersten AJ, Tassler AB, Surks MI. J Clin Endocrinol Metab. 2015; 100:337-341.

17. Busnardo B, Girelli ME, Simioni N, Nacamulli D, Busetto E. Nonparallel patterns of calcitonin and carcinoembryonic antigen levels in the follow-up of medullary thyroid carcinoma. Cancer. 1984;53:278-285.

18. Trimboli P, Giovanella L. Serum calcitonin negative medullary thyroid carcinoma: a systematic review of the literature. Clin Chem Lab Med 2015;53:1507-1514.

19. Saad MF, Ordonez NG, Guido JJ, Samaan NA. The prognostic value of calcitonin immunostaining in medullary carcinoma of the thyroid. J Clin Endocrinol Metab. 1984;59:850-856.

20. Kakudo K, Miyauchi A, Katayama S, Watanabe K. Ultrastructural study of poorly differentiated carcinoma of the thyroid. Virchows Arch A. 1987; $410: 455-460$. 